UDC 027.54(73):021

\title{
WHAT DO THEY DO AND WHAT DOES IT MEAN: IDENTICAL PRACTICES IN THE SOCIO-CULTURAL DISCOURSE OF THE LIBRARY OF CONGRESS
}

Tetiana Hranchak,

Senior Researcher at the Vernadsky

National Library of Ukraine,

Dr. Hab. in Social Communications

(Kyiv, Ukraine)

e-mail:granchakt@ukr.net

ORCID: https://orcid.org/0000-0001-7854-580X

In this paper, in an example of the Library of Congress, it has been shown how one can influence on the formation and preservation of a national identity, using the socio-cultural discourse of national libraries. This is significant because the role of libraries in the process of forming a national identity is underestimated and remains beyond the attention of scholars. At the same time, the meanings that are disseminated by libraries are an instrument for identifying key accents of the concept of national memory, which will further create the informational basis of national consciousness.

So the approaches to formation and specificity of socio-cultural discourse of the Library of Congress have been examined. The analysis focuses on the main semantic trends of the socio-cultural discourse of the Library of Congress. We substantiate the democratic approach in the construction of the socio-cultural discourse of the Library of Congress, participation of experts, librarians and users in this process, who have an opportunity to influence on what meanings are disseminated by the library and stored in the national memory. That is, the formation of a national identity takes place both from above - through the institute of the library, and from below - by the community itself.

This approach allows us to speak about the socio-cultural discourse, presented by the Library of Congress as an instrument not only for preserving national memory, strengthening and preserving identity, but also as an instrument for their transformation and development. We also argue that the democratic approach to creation a socio-cultural discourse of the library makes it possible to determine its main meanings as a reflection of social transformations.

Key words: The Library of Congress, national library, socio-cultural discourse, national memory, identity, American Memory.

\section{Introduction: Identity, Memory, Discourse}

The question of identity has always been in the center of the search for science, society and person. The answer to it determines our worldview, relationships and development prospects. As it is noted by Canadian anthropologist Mauro Peressini, the identity categories make it possible for us to understand and grasp the reality. In the constantly changing world, they enable us to put names to ourselves and to the others, form some idea of who we are and who other people are, and as certain the place we occupy along with other people in the world and society (Peressini, 1993, p. 16).

The searches for identity under conditions for establishment of information society are extraordinarily actualized, since increasing of the mobility of statuses - changes in social roles and places of residence, - global information influences, virtualization of social life, interpenetration of cultures create the basis for the blurring of identical characteristics, loss of traditional forms of group solidarity, and redefining identity in general. So, the search for identity is extremely topical. In the definition of the information society, proposed by the National Institute for Strategic Studies, the 
changes in group and individual identities are considered as a mark of a new stage in social transformations (Dubov et al., 2010, p. 6).

According to the theorists of the information society, the very issue of identity will become the key to the future relations between peoples. According to Manuel Castells' prediction, the main conflict of the information society would be a conflict between globalization trends and identity. As it is noted by the scholar, «cultural battles are the power battles of the Information Age» (Castells, 2010, p. 384).

In his turn, Samuel P. Huntington believed that future conflicts will be the conflicts between civilizations, in which the issue of mentality and culture will be the main one. He wrote: «...the fundamental source of conflict in this new world will not be primarily ideological or primarily economic. The great divisions among humankind and the dominating source of conflict will be cultural. Nation states will remain the most powerful actors in world affairs, but the principal conflicts of global politics will occur between nations and groups of different civilizations. The clash of civilizations will dominate global politics. The fault lines between civilizations will be the battle lines of the future» (Huntington, 1993, p. 22).

Earlier, at the beginning of the 20th century, the concept that the future wars won't take place for new territories and resources, but for the «souls of peoples», and they will be «rebel wars», was proposed by Evgeny Messner, lecturer at the Higher Military Science Course in Belgrade. In his book «The Mutiny - the Name of the Third World» ( «Mjatezh - imja tret'ej vsemirnoj»), published in Buenos Aires in 1960 yet (Messner, 1960), E. Messner outlined the main postulates of his theory, according to which «the soul of the enemy army, the soul of the hostile people became the most important strategic objects; the mobilization of the spirit of its own people became the most important task of the supreme strategist. Sift the spirit of the enemy and protect the own spirit from corruption - this is the point of the struggle» (Messner, 2005, p. 64).

So, today's realities extremely actualize the questions of identity, national identity, self-awareness and transfer them into the political plane.This also applies to the question of the formation and preservation of national memory as a community's consolidated representation about its history, values, traditions, its historical experience, including consensus interpretations of ambiguous and contradictory episodes.

In this regard, it is important to study the memorial practices of those documentinformation institutions, which, due to their social functions, participate in preserving of the community memory - libraries, because one of the essential (or generic, basic) social functions of libraries is a memorial function - the preservation of the fund, which contains a documented information representation of the community achievements, as well as the information, necessary for its further development.

First of all, it is about national libraries, which, by virtue of their status, are called to accumulate all the documented spiritual heritage of the nation in their funds, and hence endowed with additional capabilities - the right to a mandatory copy of the documents. As it was noted in one of my previous works, «based on the specifics of the funds of national libraries, they should be considered as influential subjects of providing state's information sovereignty, which are involved in the formation of the national information space, and fill it with information that promotes the consolidation of the nation and its progress» (Granchak, 2014, p. 29).

It should be emphasized that, despite the long experience of involvement of the libraries in political and ideological processes, today they began to perform a function rather of scientific, educational and cultural institutions, library activity lost the ideological burden and became depoliticized. However, the participation of libraries 
in the formation and preservation of national memory requires to rethink their role in socio-political processes today, outline well-considered approaches to the representation and dissemination of political and socio-cultural ideas and meanings by libraries. In this context, the study of the socio-cultural discourse of libraries, those meanings that are transmitted by libraries, actualize the values, being important for society in the public national memory, and promote the consolidation of the community on the basis of these common values, requires the scientific attention.

\section{Libraries and Discourse}

The problem of socio-cultural discourse of libraries in a connection with the issue of identity is new for librarianship, although various aspects of the socio-cultural discourse and libraries has been partially researched in terms of the representation of libraries in socio-cultural discourse (Radford and Radford, 2001; Thomas, 2001), socio-cultural discourse of public libraries (Alstad and Curry, 2003; Jaeger et al., 2013, 2014; Jaeger and Sarin, 2016), using of the method of discursive analysis to determine the level of correspondence of missions, declared by academic libraries with the tasks of parent institutions (Wadas, 2017), and as a research method in library and information services and science at whole (Frohmann, 1994; Forrester et al., 1997; Radford, 2001; Budd, 2006; Kitchens, 2012; Bolin,2017).

As a repository of discourse - that was and that is, - «a temple to the discourse of the living and dead», the library is determined by Gary P. and Marie L. Radford (2001, p. 301), who argue that «the library has the authority to determine, what shall fall within the universe of discourse defined by its boundaries, and what shall not» (Radford and Radford, 2001, p. 305). By regulating the manning policies, the library is able to construct the discourse which will be accessible for future generations. One could add to this that the access policy, in turn, forms the outlines of the discourse, which is accessible for users today. The discourse, thus formed by the library, becomes a component of the general socio-cultural discourse and influences on the transformation of the latter one.

The existing interactions between political discourse, public policy processes and public libraries, in particular, the way public libraries explain the complex current circumstances and offer the strategies for effective creation of the better future for themselves, are drawn by Paul T. Jaeger, Ursula Gorham, John Carlo Bertot and Lindsay C. Sarin $(2013,2014)$.

According to Colleen Alstad and Ann Curry (2003), the activation in participation of libraries in socio-cultural (public) discourse can provide them with the new quality, giving back the public weight to democratic values and shifting the focus of users' demands out from entertainment and recreation. Instead, libraries' self-exclusion from discussing topical social issues will lead to «the loss of civic space and the resultant lack of unmediated socialinteraction» (Alstad and Curry, 2003), which is damaging to the democracy. It is important that the idea of C. Alstad and A. Curry confirms the assumption concerning the connection between the socio-cultural discourse library push and the political aspects of social relations, although this case is not about the formation or preservation of national memory and strengthening identity but about reflection of democratic social practices.

Even more significant in the current conditions of hybrid information wars is C. Alstad and A. Curry' statement about the need to revise the approaches to libraries in socio-cultural discourse in favor of «an activist, rather than neutral, political stance and are thinking of the library's mission» (Alstad and Curry, 2003). 
The issues of socio-cultural discourse of libraries were considered by Olena Voskoboinikova-Huzieva (2016), who analyzed the socio-cultural discourse of libraries by monitoring Ukrainian libraries sites and their representations in social networks and outlined the priority directions of socio-communicative activity of libraries in Ukraine under the newest conditions.

The detailed analysis and disclosure of the specifics of the socio-cultural discourse of the national libraries in the Russian Federation and Ukraine are presented in some author's previous publications (Granchak, 2015a, Hranchak, 2015b, 2016).

At the same time, taking into account the importance of optimizing the activities of national libraries for the preservation and formation of national memory, the special significance of socio-cultural discourse of national libraries under conditions of information aggression, it is expedient to study the positive foreign experience, in particular - to study the socio-cultural discourse of one of the leading national libraries in the World - The Library of Congress.

\section{Why the Library of Congress?}

Studying the experience in building the socio-cultural discourse of the Library of Congress is actual in the context of library science for several reasons.

Firstly, the American nation is a multiethnic nation. Consequently, the consolidation of the nation around common values is an important task and the sociocultural discourse of the Library of Congress should hypothetically contribute to the solution of this problem. Accordingly, the meanings relating to such values, revealing and reflecting them, should be present in the socio-cultural discourse of the Library of Congress.

Secondly, the history of the United States has more than one episode, the attitude towards which in society for a long time was not clear and common: the civil war, the problem of equal rights for African Americans, the attitude towards the indigenous population - these issues, as well as, for example, in Ukrainian history the problem of recognition the «UPA» (Ukrainian Insurgent Army [Ukrainska povstanska armiia]), in history of Poland - the evaluations of the Polish People's Army (Armia Ludowa), for Russians - the attitude towards Stalin and so on, are the points of separation processes within the nation, creating the risks of disintegration. One of the most recent cases is the events in Charlottesville (Virginia, USA) in August 2017, related to the demolition of the monument to the General of the Confederation Robert Edward Lee, between, socalled «white racists», who opposed the demolition, and liberal activists.

Thirdly, the American nation is relatively young, but at the same time, it has a strong identity, so one can speak about success in the policy of consolidation and explore the practice of participation in the implementation of this policy of the Library of Congress.

Consequently, the proposed article is devoted to the study of the peculiarities of the socio-cultural discourse of the Library of Congress, the definition and coverage of the main meanings, disseminated by the library, its approaches to the formation and preservation of national memory.

\section{Sources and Methods}

The main sources for study of the socio-cultural discourse of the Library of Congress were the official website of the institution and the information resource «America's Story from America's Library» (http://www.americaslibrary.gov/), created by the Library of Congress. The analysis on the content of these sources made it possible to determine the library's priorities in implementing the policy of memory. 
The methodological basis of the research was determined earlier in the process of studying the socio-cultural discourse of the national libraries of Ukraine and Russia (Hranchak, 2015a, p. 14-22, 2015b, 22-27, 2016, p. 7-14). The complex of research methods includes the method of critical discursive analysis, hypothesis, social communication, dialectic, systemic, monitoring, descriptive and statistical, the method of discursive analysis is the basic one. Its application made it possible to identify the key meanings, supported and translated by the Library of Congress as an actor of the socio-communicative process in displaying and constructing the information reality. The use of social communication, system approach and dialectic method led to the study of socio-cultural discourseof the Library of Congress as a complex of systemic links between society and library, the way it reflects the meanings, relevant to a certain community here and now, or those ones that are determined by the priority of state information policy and which are integrated with the socio-cultural discourse of the library into the general socio-cultural discourse of the community, causing its transformation. The method of monitoring allowed to consider socio-cultural discourse of the Library of Congressin the dynamics for almost one and a half year - since 11.18.2016 till 03.14.2018, descriptive and statistical method - to check the hypothesis, put forward in relation to the main meanings of socio-cultural discourse of the Library of Congress, as well as to determine the specifics of its reflection in the information materials of the library.

\section{American Memory from «America's Library»}

Considering the dialectical relationship between history, memory and identity, the well-known project «American Memory» should first of all be mentioned as the most significant one. The project is being implemented by the Library of Congress. As it's written in the mission of the project, «these materials, from the collections of the Library of Congress and other institutions, chronicle historical events, people, places, and ideas that continue to shape America, serving the public as a resource for education and lifelong learning» (The Library of Congress, 2018a).

The aim of the project was to preserve the «documentary memory» of the nation and, in fact, gave it the status of a common «memorization».

The financial basis for the implementation of the project was not only the budget funds but also sponsorship proceeds in ratio of approximately 1:3, respectively. «Voting with the dollar», the public demonstrated the understanding of the importance and urgency of the project for preservation of the nation's «documentary memory» and, in fact, gave it the status of a common «memorization». So, the title «American Memory» reflects not only the contents of the collection, but also the subject of its creation.

It is important to emphasize the thematic or subject approach to systematizing the documents collections. The thematic approach to informing or organizing a library fund serves as an additional tool for formation and preservation of national memory and as such could be used to influence the user, propagate or promote certain ideological installations. After all, the sections, created by the library, structure the surrounding reality for us that is reflected in the documentary form in the library fund, creating a peculiar matrix of the concept of social, in this case, national memory. So if one could see the section «Government, Law \& Politics», we update our knowledge of the state-building process, even if we do not get acquainted with the documents presented there. The «Women's History» section, in itself, emphasizes the role of women in social life, and «Science \& Technology» testifies to the presence of some achievements in this area. 
The acquaintance at the beginning of the study, in November 2016, with the leading rubrics, formed within the framework of the project and presented on the main page of the official website of the Library of Congress - «African American History», «Art \& Architecture», «Gov't, Law \& Politics», «Literature \& Poetry», «Local History \& Folklife», «Performing Arts», «Geography \& Places», «Religion \& Philosophy», «Science \& Technology», «Social \& Business History»), «Sports \& Recreation», «War \& Military», «Women's History», «World Cultures \& History», «American History»made it possible to put forward a hypothesis about the determination by the library of the most important from the specific of the US point of view thematic emphases in this way: formation of the idea about importance of the African American component in the history of the United States, the emphasis on the aspiration of building a ruleof-law state, whose society remembers the path that took place, while fought for its rights, a state that encompasses enormous spaces and, at the same time, retains the local specificity of individual regions, with developed science, literature, art, with its religion and philosophy, which are based on a powerful economic foundation, a state that communicates with the world and recalls its own history.

The construction of such a semantic concept of socio-cultural discourse of the Library of Congressis also confirmed by the results from the analysis on the register of electronic exhibitions of the library (in total - 129 items). On March 11, 2018, among the meanings that were broadcast by the library in this way the ones that were related to the culture and talents of the nation, world culture and international context, statehood and nation-building, human, humanistic, democratic values, wars, conflicts, terrorism, territories of the country and geography, USA Afro-American History, Indigenous Peoples and America inpre-Columbian era have dominated (look at the Table 1):

Table 1.

\section{Electronic exhibitions of the Library of Congress (1992-2018)}

\begin{tabular}{lc}
\hline \multicolumn{1}{c}{ Subject } & $\begin{array}{c}\text { Number } \\
\text { on March 11, 2018 }\end{array}$ \\
\hline Culture and talents of the nation & 56 \\
\hline $\begin{array}{l}\text { Statehood (meanings, related to the Constitution, creation of the } \\
\text { United States, prominent statesmen, such as Abraham Lincoln and } \\
\text { Thomas Jefferson), American values, meanings forming the nation }\end{array}$ & 19 \\
\hline World culture and international context & 35 \\
\hline Human, humanistic, democratic values & 9 \\
\hline $\begin{array}{l}\text { Wars, conflicts, terrorism (Civil War in the USA, World War I and } \\
\text { World War II, the Korean War and Vietnam, the War in the Persian } \\
\text { Gulf, the Cold War, the problem of terrorism) }\end{array}$ & 7 \\
\hline Territory of the country and geography & 5 \\
\hline African American History of the United States & 4 \\
\hline Indigenous peoples of America, early (pre-Columbian) America & 3 \\
\hline Ecology & 3 \\
\hline Jewish themes & 1 \\
\hline Sport & 1 \\
\hline
\end{tabular}


At the same time it is remarkable that the exhibitions that are not even connected at first sight with the issues of nation-building and the state are integrated into the «identity» context by titles or descriptions. For example, in the titles of 15 from the 56 exhibitions that reflect the various aspects of the cultural development in the US, the words «America» or «American» are used in the aspect of identity: «Hope for America: Performers, Politics and Pop Culture», "American Beauties: Drawings from the Golden Age of Illustration», «Books That Shaped America», «I Love Lucy: An American Legend», «The Wizard of Oz: An American Fairy Tale» etc.

Changing the interface of the Library of Congress website in 2017, moving the headings of collections from the main page to the section «Digital Collections» and placing the Top of the library activities (different at various periods) on the main page influenced on perception of the posted information materials. In this way, the user's attention is directed not to «reading» the whole set of semantic markers, available in the socio-cultural discourse of the Library of Congress through the visual coverage of the headings, but focused on specific meanings that the library accents.

So, on March 9, 2018 it was the information about the Women's History Month, regarding which it was emphasized that the Library of Congress joins «in commemorating and encouraging the study, observance and celebration of the vital role of women in American history» (The Library of Congress, 2018h). Women's themes were supplemented by information about the exhibition «Drawn to Purpose. American Women Illustrator and Cartoonists». In addition, in the March Top Library, there were three informational materials, related to Harriet Tubman, the heroine of the American people, an African-American, a well-known abolitionist, who fought against the slavery for freedom of the African-American US population; information on Irish American Resources; materials for people with special needs.

Earlier, at the end of April 2017, the library website represented the online exhibition «Drawing Justice: the Art of Courtroom illustration» (look at the Figure 1), which, on the one hand, focused on justice as an integral component of American life, and on the other hand - on compliance with the principle of openness because the exhibition represented the drawings, made in the courtroom under the conditions of the prohibition for photographing and radio broadcasts from federal courts (The Library of Congress, 2018d).

In line with it - exhibitions, devoted to the memory of the World War I (The Library of Congress, 2018e), as well as the documents of the poet Walt Whitman (1819-1892) in the collection of Charles E. Feinberg (The Library of Congress, 2018g).

The information about exhibitions «World War I: American Artists View the Great War» (05.07.2016- 08.19.2017) (The Library of Congress, 2018i), «Echoes of the Great War: American Experiences of World War I» (04.04.2017 - 01.2019) (The Library of Congress, 2018e) (look at the Figure 2) looked somewhat unexpectedly at that time in the Library Top, because, as it is known, the United States took part in military actions as a direct participant of the World War I only in 1917-1918.

However, the global character of the war, as well as the round date - 100 years since those events, explain the presence of this topic in the top of the meanings, proposed by the Library of Congress.

From the standpoint of state and nation-building meanings, other positions of the Library «exhibition Top» are indicative: «America Reads...» (January 2017) (The Library of Congress, 2018b) and «Mapping a Growing Nation: From Independence to Statehood» (September 2016, - November 2016) (The Library of Congress, 2018f) (look at the Figure 3). 


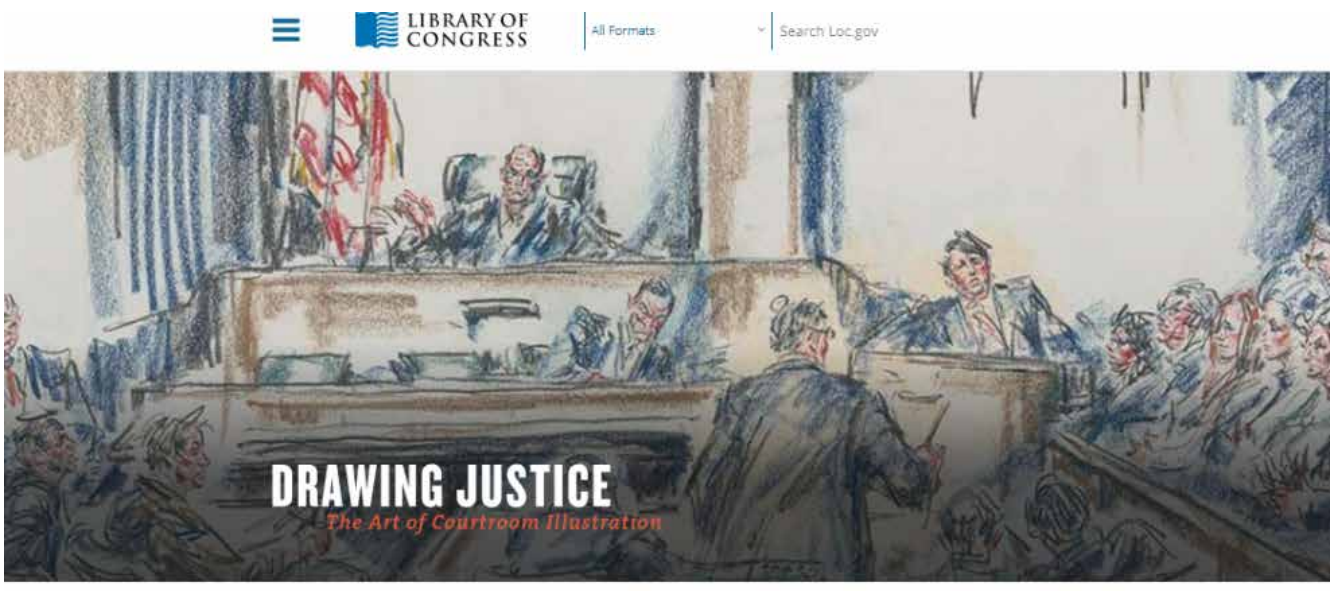

Online Exhibition | Exhibition items | Events \& Resources | Credits

Venue information April 27-January 31, 2018
This exhibition showeases the Librarys extensive collections of original art by talented artists hired by both newspit teievision to capture the personal dynamics of legal trials. Sillied at quickly cenveying both indvidual licenesses an atmosohere of the courtroom, these artists create drawings that provide insight into the drama and impact of ever lawduring the past fifty years

Figure 1. The online exhibition «Drawing Justice: the Art of Courtroom illustration» (https://www.loc.gov/exhibitions/drawing-justice-courtroom-illustrations/about-thisexhibition/)

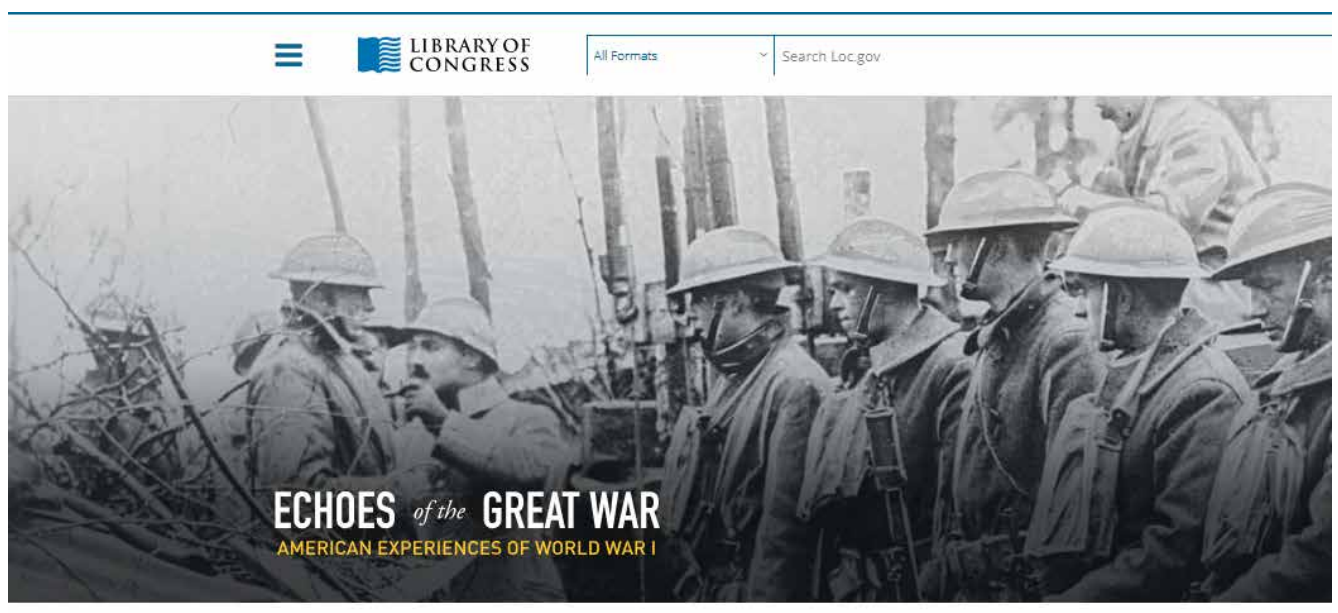

Online Exhibition | Timeline | Multimedia | Exhibition Items | Events \& Resources | Credits

Venue Information 8.30 a.m. to $4: 30$ p.m. Southwest Gallery Second Floor. Thomas jefferson Bulding
Echoes of the Great War: Americon Experiences of World Wor / examines the upheaval of World War as Americans cont both at home and abroad. The exhibition considers the debates and struggles that surrounded U.S. engagement; military and home front mobilization and the immens ty of industrialized warfare; and touches on the war's effects international peace settlement was negotiated, national borders were redrawn, and soldiers returned to reintegra: American society.

Figure 2. The online exhibition «Echoes of the Great War:

American Experiences of World War I»

(https://www.loc.gov/exhibitions/world-war-i-american-experiences/about-this-exhibition) 


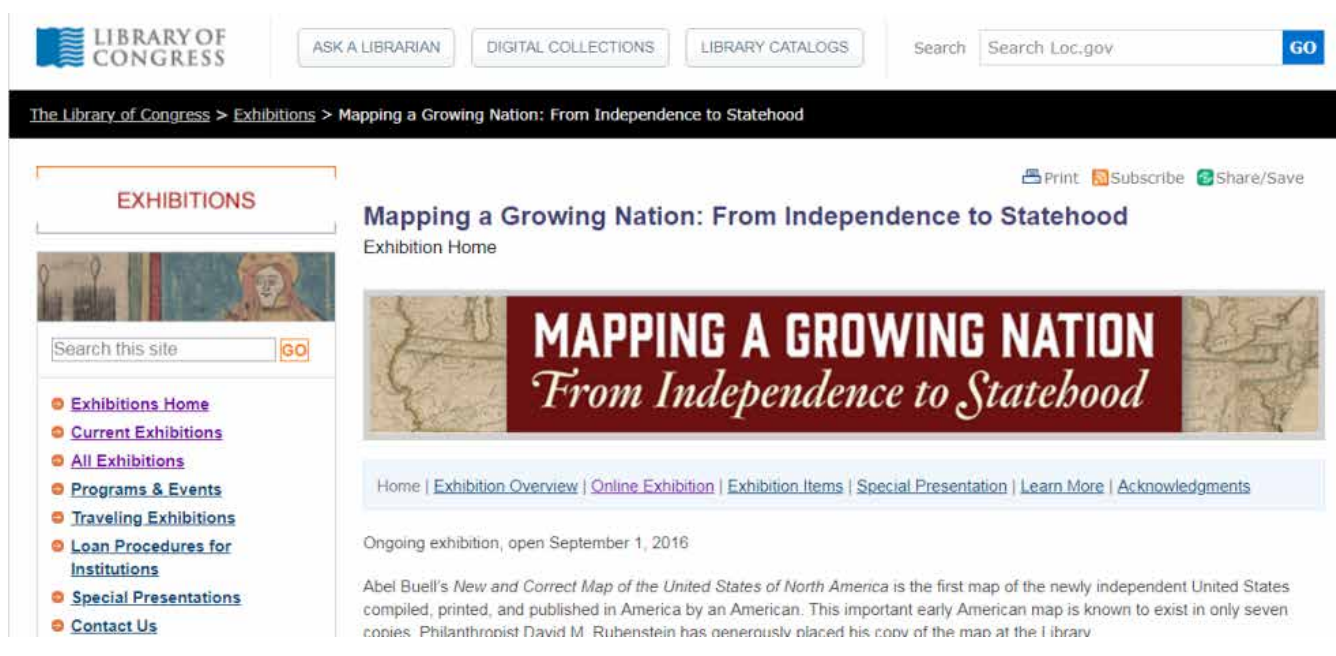

Figure 3. The online exhibition «Mapping a Growing Nation:

From Independence to Statehood»

(https://www.loc.gov/exhibits/mapping-a-growing-nation/)

As for the latter one, it was the demonstration of digital copy of the first map of the United States of America, compiled and published in America by the American Abel Buell.

The meaningful capacity of the exhibition title attracts the attention. It interprets the US map as a visual reflection of the state-building process and makes a semantic emphasis on the process of transition from independence to statehood as an embodiment of the nation's growth.

As for the exhibition «America Reads...» (look at the Figure 4) we would remind that earlier, in 2012, the Library of Congress made the initiative to organize the exhibition «Books That Shaped America». The exhibition represented 88 books (the number of books was due to the possibilities of the exhibition space at the Library of Congress), which had the impact on the national identity - from Thomas Pain's pamphlet «Common Sense» to Dr. Seuss's «Cat in a Hat».

As it was explained by the chief of the Rare Book and Special Collections Division at the Library of Congress, Mark Dimunation, who participated in the work of the committee of historians, literary experts, poets and scholars, who chose books for inclusion into the exposition, the committee was «looking for books, whether it's literature or social science or history, that ... encapsulated and reflected a moment of time in America that Americans understood and recognized in themselves» (National Public Radio, 2012).

It is noteworthy that the library's study on the issue of determining the books that influenced on formation of American nation, continues. In the meantime, according to the results of the study and readers' reviews, the Library of Congress organized the exhibition «America Reads ...», in which, along with 88 previously identified books, the top 40 other books that have formed America, selected by users, are presented.

The presented documents are systematized chronologically: from 1750 to 1899 , from 1900 to 1949 , from 1950 to 2009. 


\section{The Library of Congress > Exhibitions > America Reads}

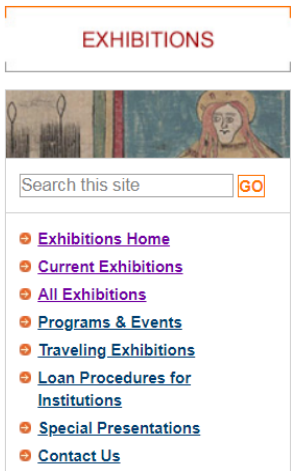

\section{America Reads}

Exhibition Home

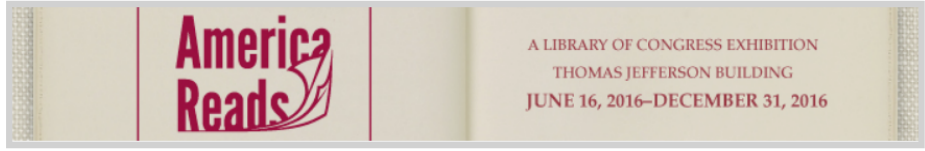

Home | Exhibition Overview | Exhibition Items | Multimedia | Learn More | Public Programs | Special Presentation | Acknowledgments

Sections: 1750 to 1899 | 1900 to 1949 | 1950 to 2009

June 16-December 31, 2016

Figure 4. The online exhibition «America Reads ...»

(https://www.loc.gov/exhibits/america-reads/)

The first section contains Thomas Pain's pamphlet «Common Sense», «The Federalist» (the eighty-five essays of Alexander Hamilton, James Madison, and John Jay), James Fenimore Cooper's «The Last of the Mohicans», Herman Melville's «MobyDick; or, The Whale», «Uncle Tom's Cabin» by Harriet Beecher Stowe, «Adventures of Huckleberry Finn» by Mark Twain and some others.

The second section includes such books as L. Frank Baum's «The Wonderful Wizard of Oz», Margaret Mitchell's «Gone With the Wind», F. Scott Fitzgerald's «The Great Gatsby», Ernest Hemingway's «The Sun Also Rises», John Steinbeck's «The Grapes of Wrath» and so on.

In the last section we find, for example, such books as «The Catcher in the Rye» by J. D. Salinger, «The Old Man and the Sea» by Ernest Hemingway, «East of Eden» by John Steinbeck, «Fahrenheit 451» by Ray Bradbury, etc.

With regard to the choice of readers, as it is noted in the description of the exhibition, «number one» in the list of Top-40 - is Ayn Rand's «The Fountainhead», «a book that has as many fans as it does detractors» (The Library of Congress, 2018b), in addition, the highest positions of the list included the works by Alex Haley, John Steinbeck, Arthur Miller, Ernest Hemingway, Milton Friedman, and, in fact, A. Rand.

Formulating the exhibition in this way, apart from adhering to the principle of democracy, enables us to identify substantial meaning for the community «from below», by the public itself, reflecting («reading») the social transformation of values, views and beliefs.

The library provides with the platform and initiates the process of comprehension and creation of socio-cultural discourse - the formation and definition of actual meanings comes from below. According to the initiators of the exhibition, it aims «to jump-start new conversations about the most influential books written and read in America and their impact on our lives» (The Library of Congress, 2018b).

This approach is now also being used by the Library of Congress to build the socio-cultural discourse of the library in the whole: if at first it reflected the vision of librarians, then, for example, in April 2017, it began to take into account the priorities of users. This was facilitated by placing of the information about popular user's queries 
on the main page of the website. The presented table shows how the user's requests during the review period changed - what meanings were lost and what kept on (look at the Table 2):

Table 2.

\section{Changes in requests from users of the Library of Congress} (18.11.2016-9.03.2018)

\begin{tabular}{cc}
\hline Date Viewing & \multicolumn{1}{c}{ Keywords of Users Queries } \\
\hline 18.11 .2016 & $\begin{array}{c}\text { Declaration of Independence; Slavery; Immigration; Territories } \\
\text { exposed to drought and dust storms; World War I; Abraham Lincoln, } \\
\text { Constitution; Genealogy }\end{array}$ \\
\hline 29.04 .2017 & $\begin{array}{c}\text { Civil War; Dry Law; Harriet Tubman; Rosa Parks (American } \\
\text { public figure, whose name is associated with the beginning of the } \\
\text { mass struggle of black people for equal rights in America); Great } \\
\text { Depression; Development of Western Lands; Today in History }\end{array}$ \\
\hline 1.10 .2017 & $\begin{array}{c}\text { CivilWar;Slavery;World War I;Alexander Hamilton; Immigration; } \\
\text { War in Vietnam; maps }\end{array}$ \\
\hline 9.03 .2018 & $\begin{array}{c}\text { Civic rights; Dorothea Lange; Civil War; Rose Parks; Dust Bowl } \\
\text { (a period of severe dust storms in the 1930s causing serious damage } \\
\text { to the United States ecology and agriculture); World War I; Baseball }\end{array}$ \\
\hline
\end{tabular}

As we see, the most persistent meanings in the socio-cultural discourse, proposed by users, were the meanings, associated with the Civil War and the struggle of African Americans against the slavery for equal rights. At the same time we also observe the actualization of the meanings, associated with the First World War, to a lesser extent with the formation of the United States as a state, immigration, the US typical environmental problems, we note the presence of markers of the Vietnam War, the Great Depression, baseball, which is popular in the US, in the users' socio-cultural discourse. All of that indicate the «memorizing» of users about these phenomena of American history.

The Library of Congress spreads the significant meanings for the formation of American identity not only through the official website but also by creating and supporting the operation of additional resources, such as «African American History Month», «Women's History Month», «America's story from America’s Library» (look at the Figure 5).

The latter one is a popular resource, designed to help shaping the notion of the United States as a state and national community by providing the brief and interesting information on prominent Americans - politicians, reformers, artists, scholars, athletes, etc. - US history, geography and administrative structure, peculiarities of states, games, sports and hobbies, cinema, music, etc (The Library of Congress, 2018c).

Designed for young people, the website is aimed at translating over time between generations the meaningful in context of American identity information and meanings. Moreover, the motivating names of headings - «Meet..», «Jump..», «Explore...», «Join...», «See, Hear and Sing» - as well as the color visual solutions and interactivity of the resource (the online games with using the presented information materials) contribute to formation an active personality, better memorization of information and connection 


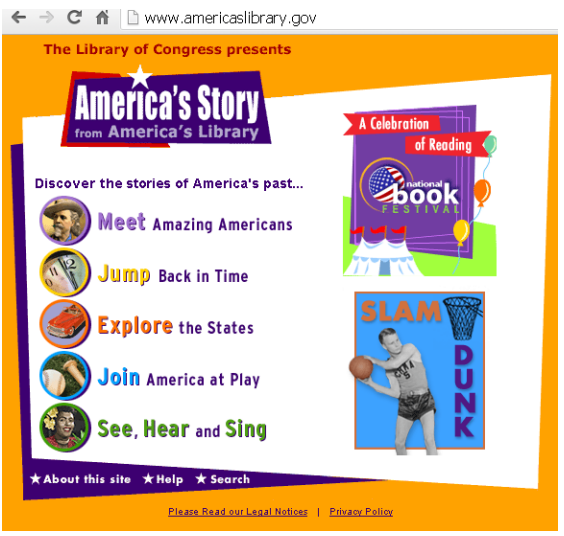

Figure 5. Website «America's story from America's Library» (http://www. americaslibrary.gov/)

of yourself, your personal history with the country and its history.

In particular, this refers to virtual travel in the past, when choosing a day and a month, the user receives the information about what happened this day in different years. At the same time one is invited to investigate what happened in the country on different years on the day of one's birth. Another game offers a visitor to the site to create their own cartoon, another one - to travel through the states, etc.

\section{Conclusions}

Summing up, it should be emphasized that the socio-cultural discourse of the Library of Congress is formed in a consistent, systematic and purposeful manner, with the understanding of the importance of preserving the key events and processes that influenced the formation of the nation in its memory, as well as the role of documentary heritage and the library activities in the solution of this task. The socio-cultural discourse of the Library of Congress contributes to the formation of the notion of the United States understanding of the U.S. as the «melting pot», in which diversity is a guaranty of personal and social success, and reflects the perception of the Americans as a nation that values the democratic rights and freedoms, creativity and active life style, that has gone a long and difficult way to build its own statehood and gaining its own place in the world, whose history contains many unpleasant and sometimes frankly tragic pages, and who does not consider it as a point of national shame and is not afraid to remember it. The specificity of the formation of the socio-cultural discourse of the Library of Congress is the democratic approach: involving the users into this process, trying to get feedback from them and willingness to broadcast the proposed meanings. This approach allows us to speak about the socio-cultural discourse, presented by the Library of Congress as an instrument not only for preserving national memory, strengthening and preserving identity but also as an instrument for their formation and transformation in accordance with the changes that society is experiencing. Moreover, bearing in mind the user's audience participation in the formation of the socio-cultural discourse of the Library of the Congress, the resulting main ideological and value markers of identity and national memory become a reflection of the development of the community, its self-awareness in the globalized world.

\section{REFERENCES}

Alstad, C., \& Curry, A. (2003). Public space, public discourse and public libraries. In Libres: Library and Information Science Research Electronic Journal. (Vol. 13, 1). Retrieved from: https:// cpb-us-e1.wpmucdn.com/blogs.ntu.edu.sg/dist/8/644/files/2014/06/Vol13_I1_pub_space. pdf [in English].

Bolin, M.K. (2017). The 21st Century Academic Library. Global Patterns of Organization and Discourse.Cambridge, MA: Chandos Publishing [in English]. 
Budd, J.M. (2006). Discourse Analysis and the Study of Communication in LIS. Library Trends (Vol. 55, 1, pp. 65-82) [in English].

Castells, M. (2010). The Information Age: Economy, Society and Culture Volume III: End of Millennium (2nd ed.) Oxford: Wiley Blackwell [in English].

Dubov, D.V., Ozhevan, M.A., \& Hnatiuk, S.L. (2010). Informatsiine suspilstvo v Ukraini: hlobalni vyklyky ta natsionalni mozhlyvosti. Analitychna dopovid [The Information Society in Ukraine: Global Challenges and National Opportunities. Analytical report]. Kyiv: Natsionalnyi instytut stratehichnykh doslidzhen. Retrieved from: http://www.niss.gov.ua/public/File/2010_table/1214_dopov.pdf [in Ukrainian].

Forrester, M.A., Ramsden, C., \& Reason, D. (1997). Conversation and discourse analysis in library and information services. In Education for Information (Vol. 15, 4, pp. 283-295) [in English].

Frohmann, B. (1994). Discourse Analysis as a Research Method in Library and Information Science. Library \& Information Science Research (Vol. 16, Issue 2, pp. 119-138). Retrieved from: https://doi.org/10.1016/0740-8188(94)90004-3 [in English].

Granchak, T. (2014). The Formation by Libraries of National Information Space in the Context of the National Information Policy. In Naukovi pratsi Natsionalnoi biblioteky Ukrainy im. V. I. Vernadskoho (Issed 39, pp. 26-42). Retrieved from: http://nbuv.gov.ua/UJRN/ npnbuimviv_2014_39_4 [in Ukrainian].

Hranchak, T. (2016). Socio-Cultural Discourse of National Libraries of Ukraine as a Tool of Formation of National Memory. Bibliotechnyi visnyk, 6, 7-4. Retrieved from: http://nbuv.gov. ua/UJRN/bv_2016_6_4 [in Ukrainian].

Hranchak, T. (2015a). Socio-Cultural Discourse of the Russia's National Libraries as a Source to Determine the Priority of Modern Russia National Memory Markers. Bibliotechnyi visnyk, 4, 14-22 [in Ukrainian].

Hranchak, T. (2015b). Ukraine and World War II: Approaches to Understanding and Representation in Socio-Cultural Discourse of National Libraries of Ukraine. Bibliotechnyi visnyk, 5, 22-27 [in Ukrainian].

Huntington, S.P. (1993). The Clash of Civilizations. In Foreign Affairs. (Vol. 72, 3, pp. 22-49) [in English].

Jaeger, P.T., Gorham, U., Bertot, J.C., \& Sarin, L.C. (2014). Public Libraries, Public Policies, and Political Processes: Serving and Transforming Communities in Times of Economic and Political Constrait. Lanham, Maryland: Rowman \& Littlefield [in English].

Jaeger, P.T., \& Sarin, L.C. (2016). The Politically Engaged Public Library: Admitting and Embracing the Political Nature of Libraries and Their Goals. In Public Library Quarterly (Vol. 35, 4, pp. 325-330) [in English].

Jaeger, P.T., Bertot, J.C., \& Gorham, U. (2013). Wake up the nation: Public libraries, policy making, and political discourse. In The Library Quarterly. Information, Community, Policy (Vol. 83, 1, pp. 61-72). https://doi.org/10.1086/668582 [in English].

Kitchens, J.D. (2012). Librarians, Historians, and New Opportunities for Discourse: A Guide for Clio's Helpers. Santa Barbara, CA: Libraries Unlimited [in English].

The Library of Congress. (2018a). About American Memory. Retrieved from: https://memory.loc. gov/ammem/about/index.html [in English].

The Library of Congress. (2018b). America Reads: Thousands of Readers Choose Books that Shaped America. Retrieved from: http://www.loc.gov/exhibits/america-reads/overview.html [in English].

The Library of Congress. (2018c). America's story from America's Library. Retrieved from: http:// www.loc.gov/exhibits/america-reads/overview.html [in English].

The Library of Congress. (2018d). Drawing Justice: the Art of Courtroom illustration. Retrieved from: https://www.loc.gov/exhibitions/drawing-justice-courtroom-illustrations/onlineexhibition/introduction/?st=gallery [in English].

The Library of Congress. (2018e). Echoes of the Great War: American Experiences of World War I. Retrieved from: https://www.loc.gov/e xhibitions/world-war-i-american-experiences/ about-this-exhibition [in English]. 
The Library of Congress. (2018f). Mapping a Growing Nation: From Independence to Statehood. Retrieved from: http://www.loc.gov/exhibits/mapping-a-growing-nation [in English].

The Library of Congress. (2018g). Walt Whitman Papers in the Charles E. Feinberg Collection. Retrieved from: https://www.loc.gov/collections/feinberg-whitman/about-this-collection [in English].

The Library of Congress. (2018h). Women's History Month. Retrieved from: http://www. womenshistorymonth.gov/ [in English].

The Library of Congress. (2018i). World War I: American Artists View the Great War. Retrieved from: https://www.loc.gov/exhibits/american-artists-view-the-great-war [in English].

Messner, E. (1960). Mjatezh - imja tret'ej vsemirnoj [The Mutiny - the Name of the Third World]. Bujenos-Ajres: Izdanie Juzhno-Amerikanskogo Otdela «Instituta dlja issledovanija problem vojny i mira imeni prof. Gen. N. N. Golovina» [in Russian].

Messner, E. (2005). Vsemirnaja mjatezhvojna [The World MutinyWar]. In Marchenkov V.I. (Ed.) Hochesh' mira, pobedi mjatezhvojnu! Tvorcheskoe nasledie E.Je. Messnera. Moscow: Voennyj universitet, Russkij put'. Retrieved from: http://militera.lib.ru/science/0/pdf/messner_ea01.pdf [in Russian].

National Public Radio. (2012). How Books Shaped The American National Identity. Retrieved from: http://www.npr.org/2012/08/14/158771705/-books-that-shaped-america [in English].

Peressini, M. (1993). Identity - a Card with Two Faces. UNESCO Courier. June, 14-18. Retrieved from: http://unesdoc.unesco.org/images/0009/ 000944/094420eo.pdf [in English].

Radford, G.P., \& Radford, M.L. (2001). Libraries, Librarians, and the Discourse of Fear. In The Library Quarterly: Information, Community, Policy (Vol. 71, 3 (Jul.), pp. 299-329). Retrieved from: https://www.researchgate.net/ publication/249120469_Libraries_Librarians_and_ the_Discourse_of_Fear [in English].

Radford, M.L. (2001). Encountering Users, Encountering Images: Communication Theory and the Library Context. In Journal of Education for Library and Information Science (Vol. 42, 1, pp. 27-41) [in English].

Thomas, N.P. (2001). Unpacking Library Posters: A Theoretical Approach. In Journal of Education for Library and Information Science (Vol. 42, 1, pp. 42-56) [in English].

Voskoboinikova-Huzieva, O. (2016). The Socio-Communication Activites of Libraries of Ukraine in Latest Conditions. Bibliotechnyi visnyk, 1, 12-17. Retrieved from: http://nbuv.gov.ua/ UJRN/bv_2016_1_4 [in Ukrainian].

Wadas, L.R. (2017). Mission statements in academic libraries: a discourse analysis. In Library Management (Vol. 38, issue 2-3, pp. 108-116). Retrieved from: https://doi.org/10.1108/ LM-07-2016-0054 [in English].

УДК 027.54(73):021

Тетяна Гранчак, старший науковий співробітник Національної бібліотеки України імені В. І. Вернадського, д-р наук із соціальних комунікацій, ст. наук. співроб. (Київ, Україна) e-mail:granchakt@ukr.net ORCID: https://orcid.org/0000-0001-7854-580X

\section{ЩО ВОНИ РОБЛЯТЬ І ЩО ЦЕ ОЗНАЧАЄ: ІДЕНТИЧНІСНІ ПРАКТИКИ В СОЦІОКУЛЬТУРНОМУ ДИСКУРСІ БІБЛІОТЕКИ КОНГРЕСУ}

У статті на прикладі Бібліотеки Конгресу було показано, як можна впливати на формування та збереження національної ідентичності, використовуючи соціокультурний дискурс національних бібліотек. Це важливо, оскільки, роль бібліотек у процесі формування національної ідентичності недооцінюється і залишається поза увагою вчених. Водночас 
смисли, що поширюються бібліотеками, є інструментом для виявлення ключових акцентів концепту національної пам'яті, яка надалі створюватиме інформаційну основу національної самосвідомості.

Отже, в публікації розглянуто підходи до формування та специфіку соціокультурного дискурсу Бібліотеки Конгресу. Аналіз зосереджений на основних семантичних тенденціях соціокультурного дискурсу Бібліотеки Конгресу. Виявлено демократичний підхід у конструюванні соціокультурного дискурсу Бібліотеки Конгресу, розкрито участь експертів, бібліотекарів та користувачів у цьому процесі, які мають можливість впливати на те, які смисли поширюються бібліотекою та зберігаються у національній пам'яті. Обгрунтовано, що формування національної ідентичності відбувається як згори - через інститут бібліотеки, так і знизу - самою спільнотою.

Такий підхід дає змогу говорити про соціокультурний дискурс, представлений Бібліотекою Конгресу, як інструмент не лише для збереження національної пам'яті, зміцнення та збереження ідентичності, а й як інструмент їх трансформації та розвитку. Стверджується, що демократичний підхід до створення соціокультурного дискурсу бібліотеки дає змогу визначати його основні значення як відображення соціальних перетворень.

Ключові слова: Бібліотека Конгресу, національна бібліотека, соціокультурний дискурс, національна пам'ять, ідентичність, Пам'ять Америки. 